\title{
DEVELOPING AND CHARACTERIZATION OF AN ULTRAFINE FILTER MADE OF BANANA LEAF AND WATER HYACINTH TO REDUCE MOTORCYCLE EMISSION
}

\author{
HAJAR, U. - WARDOYO, A. Y. P. ${ }^{*}$ - MASRUROH \\ Laboratory of Air Quality and Astro Imaging Department of Physics, Brawijaya University \\ Jl. Veteran 65145, Malang, East Java, Indonesia \\ (phone: +62-341-575-833; fax: +62-341-585-834) \\ *Corresponding author \\ e-mail:a.wardoyo@ub.ac.id \\ (Received $18^{\text {th }}$ Oct 2018; accepted $2^{\text {nd }}$ Jan 2019)
}

\begin{abstract}
PM}_{0.1}$ (ultrafine particles) emitted by motorcycles have been known as the major contributors to air pollution, and have a harmful impact on human health. Therefore, there is a need to decrease the concentration in the ambient air. In this study, we developed an ultrafine particle filter that was made of banana leaf powder $\left(\mathrm{F}_{\mathrm{b}}\right)$ and water hyacinth powder (Eichhornia crassipes, $\left.\mathrm{F}_{\mathrm{wh}}\right)$. The powder was mixed to glutinous rice glue in the ratio of $80 \%: 20 \%$. The filter was characterized by the efficiency. The efficiency of the filter in reducing the ultrafine particles was determined by measuring the ultrafine particle concentration before and after passing through the filter. The ultrafine particle concentration was measured using the TSI P-Trak Ultrafine Particle Counter (Model 8525) for an hour with the sampling time interval of $5 \mathrm{~min}$. The microstructure and the element contents of the filter were analyzed by an SEM and EDAX to determine the filter porosity and the filter element compound. The results show that the porosities were found $33 \%\left(\mathrm{~F}_{\mathrm{b}}\right)$ and $21 \%\left(\mathrm{~F}_{\mathrm{wh}}\right)$ and the filter contained organic and inorganic compounds. The filter efficiency was in the range of $55 \%$ to $64 \%$ for $\mathrm{F}_{\mathrm{b}}$ and $35 \%$ to $59 \%$ for $\mathrm{F}_{\mathrm{wh}}$, respectively.
\end{abstract}

Keywords: ultrafine particle filter, motorcycle emission, banana leaf, water hyacinth, efficiency

\section{Introduction}

The usage of motorcycles has been increasing from year to year (Burke et al., 2017; Guerra, 2017). As a consequence, they produce more emissions that are classified into gas and particulate matter (PM) emissions (Grieshop et al., 2006). In terms of particulate matter with the diameter less than $0.1 \mu \mathrm{m}$ (known as $\mathrm{PM}_{0.1}$ or ultrafine particle), $\mathrm{PM}_{0.1}$ deposits deeper into the lung (Clifford et al., 2018) and kidney (Wardoyo et al., 2018). Previous studies have showed the correlation between $\mathrm{PM}_{0.1}$ and human health (Chen et al., 2016; Li et al., 2016; Liu et al., 2018; Solaimani et al., 2017). Therefore, there is a need to develop a particulate filtration technology in reducing the $\mathrm{PM}_{0.1}$ concentration generated by motor vehicles.

The particulate filtration system has been developed, such as radiation based filter, electrostatic based filter, and porosity based filter (Barone et al., 2010; Budianto and Wardoyo, 2016; Wardoyo et al., 2016, 2017a). Meanwhile, the resulted filtration technology is not sufficient due to the high cost of the filter production. In this study, we developed lowcost $\mathrm{PM}_{0.1}$ filters that were made of water hyacinth $\left(\mathrm{F}_{\mathrm{wh}}\right)$ and banana leaf $\left(\mathrm{F}_{\mathrm{b}}\right)$. Those two filter ingredients can be easily found in Indonesia. They also have a high cellulose content (25-39\%) (Istirokhatun et al., 2015; Nada et al., 2010) that can adsorb ultrafine particles. Filter porosity can determine the level of adsorption (Ma et al., 2016). The aim of this study was to develop an ultrafine particle filter made of water hyacinth and banana leaf and to characterize the efficiency and the influence factors in terms of the porosity and the element compounds. 


\section{Materials and methods}

\section{Motorcycle samples}

Three motorcycles were used as $\mathrm{PM}_{0.1}$ source. They were classified into M1 (model year: 2015), M2 (model year: 2011), and M3 (model year: 2013). All of them had automatic transmission engines with the same engine capacity $\left(108 \mathrm{~cm}^{3}\right)$. They were chosen due to their prevalence in Indonesia.

\section{PMo.1 filter}

Water hyacinth and banana leaves were collected from the rivers and farms of Sengonagung village, Pasuruan, Indonesia. They were cut into small pieces, blended (diameter $\pm 70 \mathrm{mesh}$ ) and dried in an oven for seven hours (controlled temperature: $100{ }^{\circ} \mathrm{C}$ ). After that, the resulted powder (16 grams) was mixed with water $(190 \mathrm{ml})$ and a tapioca glue containing glutinous rice (4 grams) which was heated with water $(100 \mathrm{ml})$. The filter dough was printed into a layer.

\section{Particle measurement}

Each filter was installed on a filter frame (diameter $=50 \mathrm{~mm}$ ) and mounted on the tip of the motorcycle exhaust. The $\mathrm{PM}_{0.1}$ concentrations emitted by the motorcycle samples before $\left(C_{o}\right)$ and after being equipped with the filters $\left(C_{i}\right)$ were measured using a P-Trak Ultrafine Particle Counter (Model 8525) for an hour in an idle condition (sampling time $=5 \mathrm{~min}$ ). All measurements were repeated three times (Wardoyo et al., 2015).

\section{Filter characterization}

The filter was characterized by the porosity and the element compounds. The porosity was analyzed by using a scanning electron microscope analyzer INSPECT S50 SEM EDAX to determine the filterability in capturing $\mathrm{PM}_{0.1}$ emission and the structure of the morphological surface (Van der Zande et al., 2014). The element compounds were analyzed using an EDAX (Kedar et al., 2018).

\section{Statistical analysis}

Values are expressed as the means $\pm \mathrm{SD}$ (standard deviation). The differences between the groups were evaluated using a Student's $t$-test. The relationship between $\mathrm{PM}_{0.1}$ concentrations and time series was determined using R-square value (Wardoyo et al., 2017b). The filter efficiency ( $\% F)$ was calculated using Equation 1 (Mondal et al., 2015):

$$
\% \mathrm{~F}=\left[\left(\mathrm{C}_{0}-\mathrm{C}_{\mathrm{i}}\right) / \mathrm{C}_{\mathrm{o}}\right] \times 100 \%
$$

\section{Results and discussion}

\section{Emission measurement}

Figure 1 represents the comparison of the $\mathrm{PM}_{0.1}$ concentration measurement of all motorcycles without a filter and using a filter $\left(\mathrm{F}_{\mathrm{wh}}\right.$ and $\left.\mathrm{F}_{\mathrm{b}}\right)$. According to Figure 1 , the $\mathrm{PM}_{0.1}$ concentrations without being filtered are $19,020 \pm 2,958$ to $62,362 \pm 3,664$ particle $/ \mathrm{cm}^{3}$. These concentrations are higher than the $\mathrm{PM}_{0.1}$ concentrations obtained from $\mathrm{F}_{\mathrm{b}}$ and $\mathrm{F}_{\mathrm{wh}}$. 


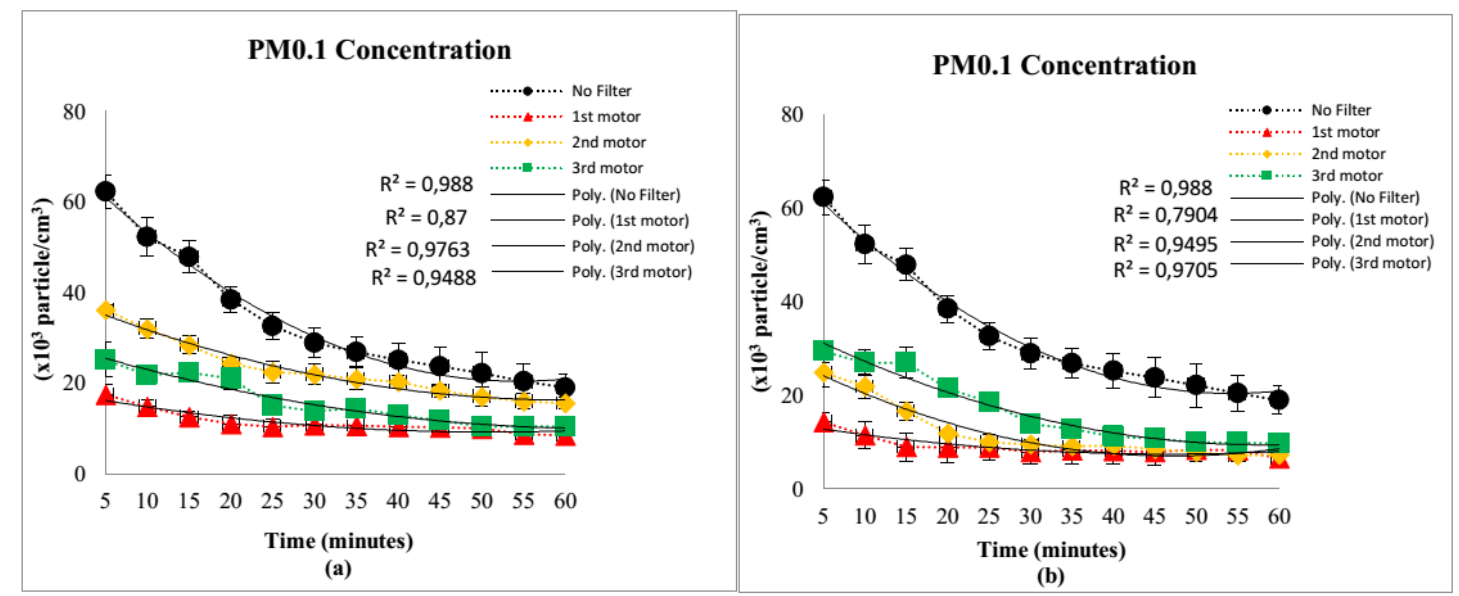

Figure 1. The PM $M_{0.1}$ concentrations of $(a) F_{w h}$ and $(b) F_{b}$

In contrast, the $\mathrm{PM}_{0.1}$ concentrations obtained from using $\mathrm{F}_{\mathrm{wh}}$ are $8,554 \pm 389$ to $36,136 \pm 1,218$ particles $/ \mathrm{cm}^{3} . \mathrm{F}_{\mathrm{b}}$ has the lowest $\mathrm{PM}_{0.1}$ concentration $(6,565 \pm 1,125$ to $29,448 \pm 2,307$ particles $\left./ \mathrm{cm}^{3}\right)$. The decreasing trend of the particle concentrations measured in all motorcycles is a polynomial trend with the order of 2 . The R-square values of all motors using the filters are in the range of 0.79 to 0.98 . If the R-square value is higher than 0.75 it presents a good relationship between the two variables on the graph (Duarte et al., 2014). Figure 2 shows the average efficiency of $F_{w h}$ and $F_{b}$ on M1 and M2. According to Figure 2, the efficiency of $\mathrm{F}_{\mathrm{b}}(55 \%$ to $63 \%)$ is higher than $\mathrm{F}_{\mathrm{wh}}(35 \%$ to $59 \%)(p<0.05)$.

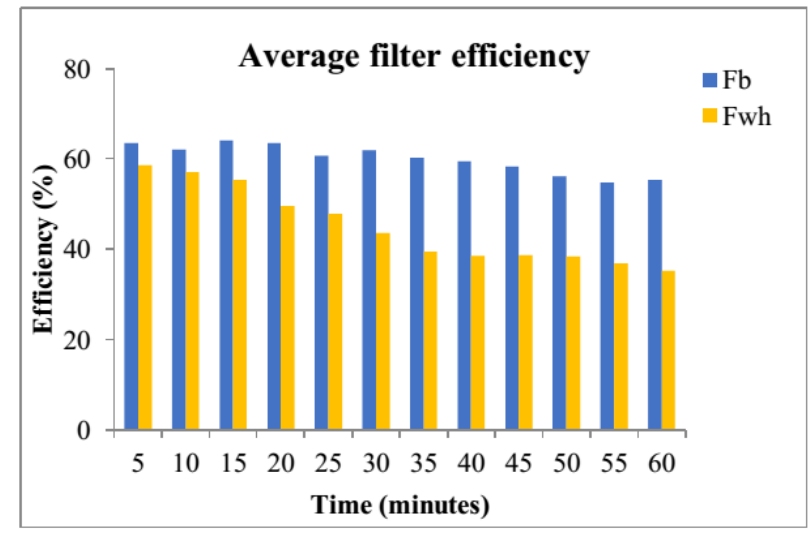

Figure 2. Average efficiencies of $F_{w h}$ and $F_{b}$

The filter efficiencies were influenced by the content of cellulose in water hyacinth and banana leaf. Cellulose content in banana leaf is 39.2\% (Nada et al., 2010) higher than cellulose content that is found in water hyacinth (25\%) (Istirokhatun et al., 2015). Cellulose can bind the organic PAHs (Polycyclic Aromatic Hydrocarbons) and VOCs (Volatile Organic Compounds)) and inorganic content of $\mathrm{PM}_{0.1}$ (Hokkanen et al., 2016; Liu et al., 2016). This is shown by the overall values of the weight percent of detected elements in $\mathrm{F}_{\mathrm{wh}}$ and $\mathrm{F}_{\mathrm{b}}$ after emission exposure as listed in Table 1. The most detected elements in Table 1 are oxygen $(\mathrm{O})$ and carbon $(\mathrm{C})$. The spherical carbon was indicated 
as one of the elements of the particles emitted by a gasoline operated vehicle (Ritovski et al., 1999). Carbon and oxygen are also the part of VOC and PAH content in $\mathrm{PM}_{0.1}$ (Charron and Harrison, 2003; Hong-li et al., 2017). VOC contains aldehydes, alkenes, and aromatic rings (Zhang et al., 2018). The aldehydes occur as $\mathrm{C}=\mathrm{O}$ stretching vibration, alkenes and aromatic rings occur as $\mathrm{C}=\mathrm{C}$ stretching vibration. While one of the PAH content in $\mathrm{PM}_{0.1}$ is perylene $\left(\mathrm{C}_{20} \mathrm{H}_{12}\right)$ (Charron and Harrison, 2003). So, thus elements $\mathrm{C}$ and $\mathrm{O}$ in Table 1 may be a part of the VOC and $\mathrm{PAH}$ in $\mathrm{PM}_{0.1}$.

Table 1. Elemental analysis of $F_{w h}$ and $F_{b}$ after emission exposure

\begin{tabular}{ccc}
\hline \multirow{2}{*}{ Element } & \multicolumn{2}{c}{ Weight $(\boldsymbol{\%})$} \\
\cline { 2 - 3 } & $\mathbf{F}_{\mathbf{w h}}$ & $\mathbf{F}_{\mathbf{b}}$ \\
\hline $\mathrm{C}$ & 28.62 & 54.30 \\
$\mathrm{O}$ & 29.35 & 33.65 \\
$\mathrm{Mg}$ & 0.67 & 0.57 \\
$\mathrm{Si}$ & 0.42 & 0.63 \\
$\mathrm{~Pb}$ & 2.44 & 1.22 \\
$\mathrm{~K}$ & 20.22 & 5.17 \\
$\mathrm{Ca}$ & 1.40 & - \\
$\mathrm{Fe}$ & 0.76 & 0.73 \\
$\mathrm{Co}$ & - & 0.23 \\
\hline
\end{tabular}

The SEM EDAX results also showed the presence of several inorganic elements, e.g. $\mathrm{Ca}$ (only detected on $\mathrm{F}_{\mathrm{b}}$ ), and $\mathrm{Co}$ (only detected in $\mathrm{F}_{\mathrm{w}}$ ). Other elements $(\mathrm{Ca}, \mathrm{Fe}$, and $\mathrm{K}$ ) are related to the crustal matter (Zhang et al., 2014). Inorganic elements that have the highest weight percent are $\mathrm{K}$ then $\mathrm{Pb}$.

In addition, the filter efficiency is also influenced by the filter porosity. Filter porosity can be known from the micrographic structure of the filter. Figure 3 shows the micrographic structure of SEM result from the processing ImageJ software (Igathinathane et al., 2008) on $\mathrm{F}_{\mathrm{wh}}$ and $\mathrm{F}_{\mathrm{b}}$ before emissions exposure. Figure 3 shows the surface pores of the filter (black). According to the figure, $\mathrm{F}_{\mathrm{wh}}$ has pores sizes in the range of $1.019 \mu \mathrm{m}^{2}$ to $1.499 \mathrm{~mm}^{2}$, with a total porosity of $21 \%$. Meanwhile, $\mathrm{F}_{\mathrm{b}}$ has pore sizes in the range of $1.038 \mu^{2}$ to $1.613 \mathrm{~mm}^{2}$, with a total porosity of $33 \%$. With the size area porosity, the filter has a potential to trap the particulate matters with a diameter of $0.1 \mu \mathrm{m}$.
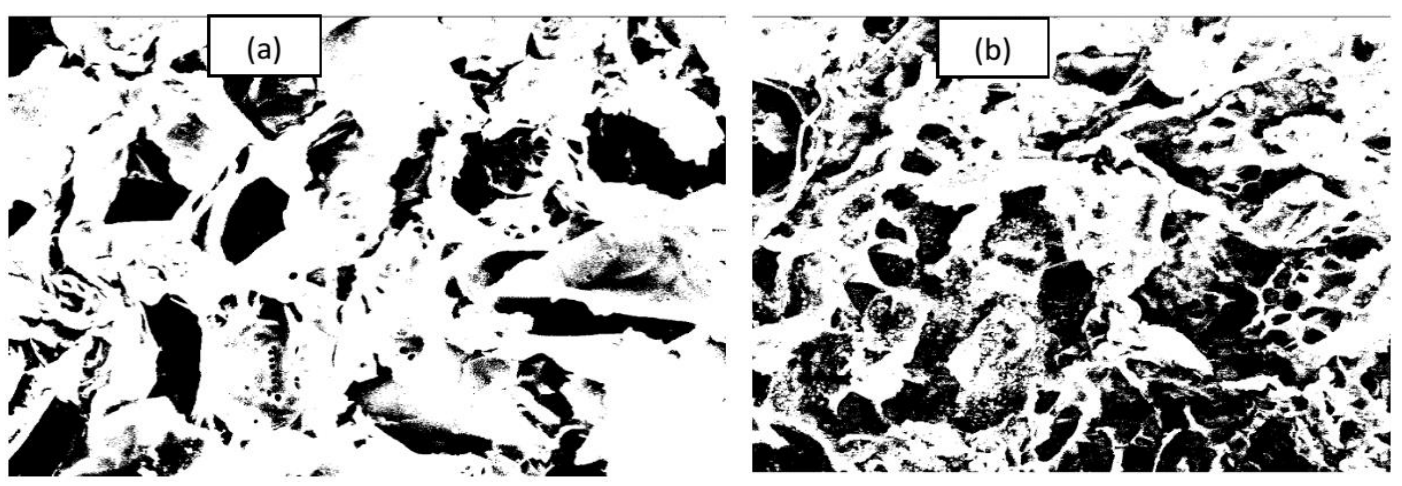

Figure 3. Micrographic SEM of imageJ processing results of the filters before being tested: (a) $F_{w h}$ and $(b) F_{b}$ 
The particles can be trapped in the filter pores with several mechanisms, i.e. inertial impaction, interception, and diffusion. Inertial impaction occurs when the particles pass through the filter with micrometer range and the particles hit the filter materials, so the particles trapped in the filter. Interception mechanism occurs when the center of the particle is shorter than the radius of the filter so the particle center does not touch the surface of the filter material to be deposited. Particles that move in the nanometer range generate Brownian motion, which causes the particles to collide with inertial or interception particles and diffuse on the surface and deposit during the time when they are passing the side of the filter (Liu et al., 2016).

Figure 4 shows the results of the water hyacinth filters before and after emissions exposure and banana leaf filters before and after emissions exposure. Figure $4 a$ and $c$ shows the cavities on the surface of the filters. Meanwhile, Figure $4 b$ and $d$ shows the invisible cavities and trapped particles on the surface of the filter. These results are similar to the results obtained in the Van der Zande et al. (2014).
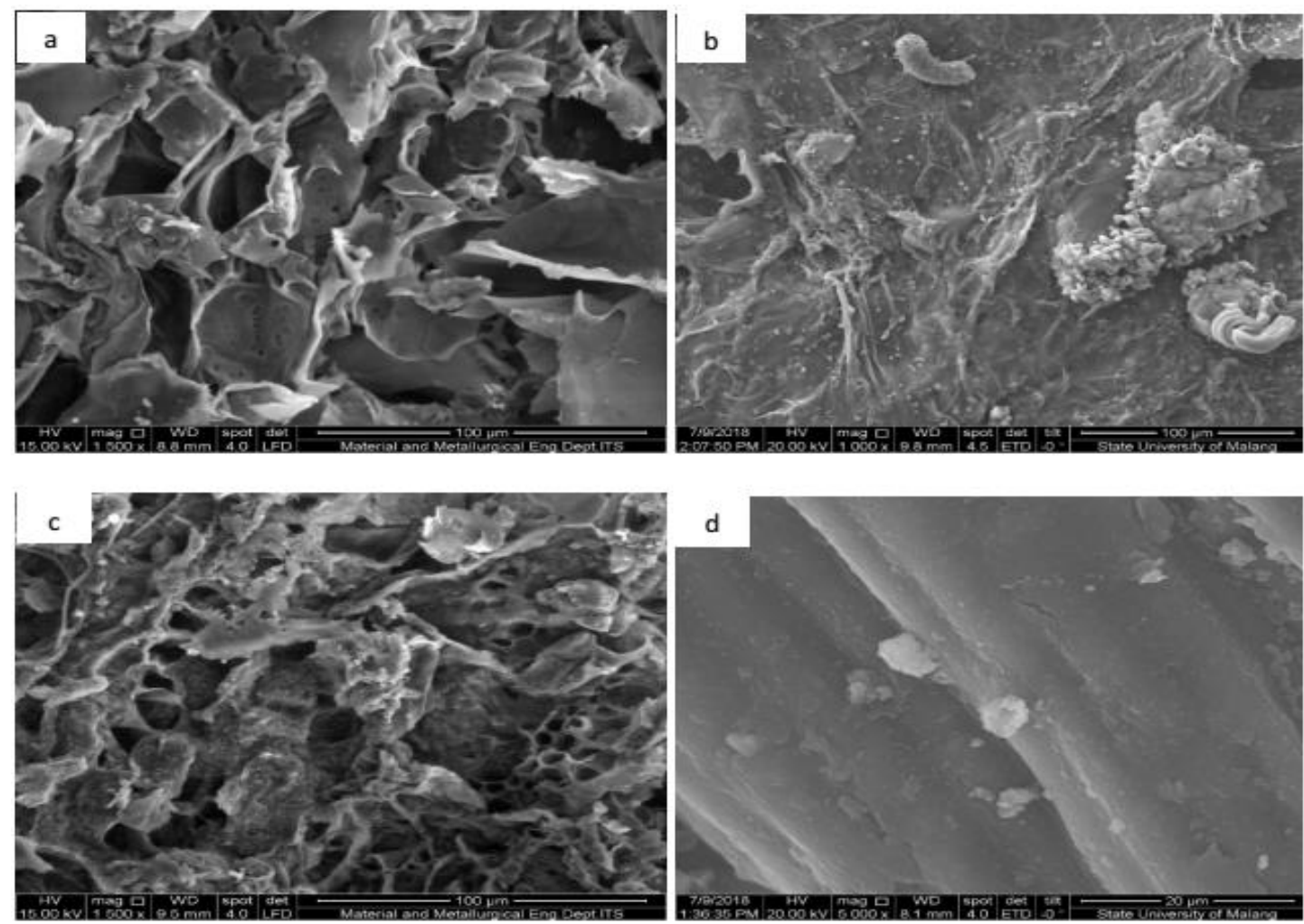

Figure 4. SEM image of $F_{w h}$ before $(a)$ and after $(b)$ being tested, and $F_{b}$ before $(c)$ and after $(d)$ being tested

\section{Conclusion}

In conclusion, the filters based on water hyacinth and banana leaf have a character to reduce the $\mathrm{PM}_{0.1}$ concentrations with the efficiency of up to $59 \%$ and $64 \%$, respectively. The filter efficiency is influenced by the cellulose content which can adsorb the organic and inorganic content of $\mathrm{PM}_{0.1}$, which is proven by the presence of several $\mathrm{PM}_{0.1}$ elements in the filter. Efficiency is also influenced by the filter porosity. $\mathrm{F}_{\mathrm{b}}$ porosity is $33 \%$ higher than $\mathrm{F}_{\mathrm{wh}}(21 \%)$, so the efficiency of $\mathrm{F}_{\mathrm{b}}$ is also higher than $\mathrm{F}_{\mathrm{wh}}$. 
Acknowledgements. Authors extend their sincere thanks to the laboratory crews of Air Quality and Astro Imaging, Department of Physics Brawijaya University, for their kind cooperation and necessary instrumental help.

\section{REFERENCES}

[1] Barone, T. L., Storey, J. M. E., Domingo, N. (2010): An analysis of field-aged diesel particulate filter performance : particle emissions before, during, and after regeneration. Journal of Air Waste Management Association 60: 968-976.

[2] Budianto, A., Wardoyo, A. Y. P. (2016): DC low electrostatic voltage particulate filter : PM 0.1 and PM 2.5 emission efficiency measurement. - International Seminar on Sensors, Instrumentation, Measurement and Metrology (ISSIMM). IEEE Advancing Technology for Humanity, Malang, pp. 115-118.

[3] Burke, P. J., Batsuuri, T., Halley, M. (2017): Easing the traffic: The effects of Indonesia's fuel subsidy reforms on toll-road travel. - Transportation Research Part A 105: 167-180.

[4] Charron, A., Harrison, R. M. (2003): Primary particle formation from vehicle emissions during exhaust dilution in the roadside atmosphere. - Atmospheric Environment 37: 4109-4119.

[5] Chen, M., Li, B., Sang, N. (2016): Particulate matter (PM2.5) exposure seasondependently induces neuronal apoptosis and synaptic injuries. - Journal of Environmental Sciences 54: 1-10.

[6] Clifford, S., Mazaheri, M., Salimi, F., Ezz, W. N., Yeganeh, B., Low-Choy, S., Walker, K., Mengersen, K., Marks, G. B., Morawska, L. (2018): Effects of exposure to ambient ultrafine particles on respiratory health and systemic inflammation in children. Environment International 114: 167-180.

[7] Duarte, G. O., Gonçalves, G. A., Farias, T. L. (2014): A methodology to estimate realworld vehicle fuel use and emissions based on certification cycle data. - Procedia - Social and Behavioral Sciences 111: 702-710.

[8] Grieshop, A. P., Lipsky, E. M., Pekney, N. J., Takahama, S., Robinson, A. L. (2006): Fine particle emission factors from vehicles in a highway tunnel: Effects of fleet composition and season. - Atmospheric Environment 40: S287-S298.

[9] Guerra, E. (2017): Electric vehicles, air pollution, and the motorcycle city: A stated preference survey of consumers' willingness to adopt electric motorcycles in Solo, Indonesia. - Transportation Research Part D. https://doi.org/10.1016/j.trd.2017.07.027.

[10] Hokkanen, S., Bhatnagar, A., Sillanpää, M. (2016): A review on modification methods to cellulose-based adsorbents to improve adsorption capacity. - Water Research 91: 1-72.

[11] Hong-li, W., Sheng-ao, J., Sheng-rong, L., Qing-yao, H., Li, L., Shi-kang, T., Cheng, H., Li-ping, Q., Chang-hong, C. (2017): Volatile organic compounds (VOCs) source profiles of on-road vehicle emissions in China. - Science of Total Environment 607-608: 253261.

[12] Igathinathane, C., Pordesimo, L. O., Columbus, E. P., Batchelor, W. D., Methuku, S. R. (2008): Shape identification and particles size distribution from basic shape parameters using ImageJ. - Computers and Electronics in Agriculture 63: 168-182.

[13] Istirokhatun, T., Rokhati, N., Rachmawaty, R., Meriyani, M. (2015): Cellulose Isolation from Tropical Water Hyacinth for Membrane Preparation. - Procedia Environmental Science 23: 274-281.

[14] Kedar, K. A., Chaudhari, S. R., Rao, A. S. (2018): Dataset on leaf surface and elemental study of four species of Bignoniaceae family by SEM-EDAX. - Data in Brief 17: 11881195 .

[15] Li, N., Georas, S., Alexis, N., Fritz, P., Xia, T., Williams, M. A., Horner, E., Nel, A. (2016): A work group report on ultrafine particles (American Academy of Allergy, 
Asthma \& Immunology): Why ambient ultrafine and engineered nanoparticles should receive special attention for possible adverse health outcomes in human subjects. Journal of Allergy and Clinical Immunology 138: 386-396.

[16] Liu, J., Hsiao, T., Lee, K., Chuang, H., Cheng, T., Chuang, K. (2018): Association of ultrafine particles with cardiopulmonary health among adult subjects in the urban areas of northern Taiwan. - Science of the Total Environment 627: 211-215.

[17] Liu, X., Souzandeh, H., Zheng, Y., Xie, Y., Zhong, W. (2016): Soy protein isolate/bacterial cellulose composite membranes for high efficiency particulate air filtration. - Composites Science and Technology.

[18] Ma, X., Liu, C., Anderson, D. P., Chang, P. R. (2016): Porous cellulose spheres: Preparation, modification and adsorption properties. - Chemosphere 165: 399-408.

[19] Mondal, N. K., Bhaumik, R., Datta, J. K. (2015): Removal of fluoride by aluminum impregnated coconut fiber from synthetic fluoride solution and natural water. Alexandria Engineering Journal 54: 1273-1284.

[20] Nada, A. M. A., El-Gendy, A. A., Mohamed, S. H. (2010): Banana leaves as adsorbents for removal of metal ions from waste water. - Carbohydrate Polymers 82: 1025-1030.

[21] Ritovski, Z., Agranovski, V., Bostrom, T. E., Thomas, S., Hitchins, J., Morawska, L. (1999): Elemental composition of combustion emissions from spark ignition vehicles. Journal of Aerosol Science 30: 845-846.

[22] Solaimani, P., Saffari, A., Sioutas, C., Bondy, S. C., Campbell, A. (2017): NeuroToxicology Exposure to ambient ultra fine particulate matter alters the expression of genes in primary human neurons. - Neurotoxicology 58: 50-57.

[23] Van der Zande, M., Vandebriel, R. J., Groot, M. J., Kramer, E., Herrera Rivera, Z. E., Rasmussen, K., Ossenkoppele, J. S., Tromp, P., Gremmer, E. R., Peters, R. J. B., Hendriksen, P. J., Marvin, H. J. P., Hoogenboom, R. L. A. P., Peijnenburg, A. A. C. M., Bouwmeester, H. (2014): Sub-chronic toxicity study in rats orally exposed to nanostructured silica. - Particle Fibre Toxicology 11: 1-19.

[24] Wardoyo, A. Y. P., Juswono, U. P., Valentino, A., Huda, F. B. (2015): Quantification of ultrafine particle emission factors from motor bikes. - International Journal of Applied Engineering Research 10: 40276-40281.

[25] Wardoyo, A. Y. P., Juswono, U. P., Riyanto, S. (2016): Developing particulate thin filter using coconut fiber for motor vehicle emission. - AIP Conference Proceedings 1719.

[26] Wardoyo, A. Y. P., Nuriyah, L., Darmawan, H. A., Firdaus, M. I., Adi, E. T. P. (2017a): Developing reheated filter of motorcycle exhaust for reducing PM2.5 emissions. Proceedings 2017 International Seminar on Sensor, Instrumentation, Measurement and Metrology: Innovation for the Advancement and Competitiveness of the Nation, IEEE Advancing Technology for Humanity, pp. 42-45.

[27] Wardoyo, A. Y. P., Juswono, U. P., Noor, J. A. E. (2017b): A study of the correlation between ultrafine particle emissions in motorcycle smoke and mice erythrocyte damages. - Experimental and Toxicologic Pathology 69: 649-655.

[28] Wardoyo, A. Y. P., Juswono, U. P., Noor, J. A. E. (2018): Varied dose exposures to ultrafine particles in the motorcycle smoke cause kidney cell damages in male mice. Toxicology Reports 5: 383-389.

[29] Zhang, N., Cao, J., Liu, S., Zhao, Z., Xu, H., Xiao, S. (2014): Chemical composition and sources of PM2.5 and TSP collected at Qinghai Lake during summertime. - Atmospheric Research 138: 213-222.

[30] Zhang, Q., Wu, L., Fang, X., Liu, M., Zhang, J., Shao, M., Lu, S., Mao, H. (2018): Emission factors of volatile organic compounds (VOCs) based on the detailed vehicle classification in a tunnel study. - Science of the Total Environment 624: 878-886. 